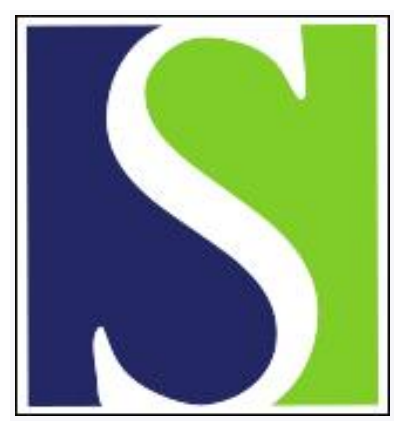

Scand J Work Environ Health 1981;7(2):109-113

https://doi.org/10.5271/sjweh.2559

Issue date: Jun 1981

Inorganic fibers in lung tissue from patients with pleural plaques or malignant mesothelioma.

by Gylseth B, Mowé G, Skaug V, Wannag A

Key terms: asbestos-related disease; inorganic fiber; lung; lung tissue; malignant mesothelioma; occupation; patient; pleural plaque; scanning electron microscopy

This article in PubMed: www.ncbi.nlm.nih.gov/pubmed/7313614

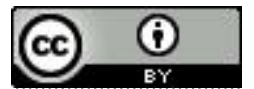




\title{
Inorganic fibers in lung tissue from patients with pleural plaques or malignant mesothelioma
}

\author{
by Bjørn Gylseth, MSc, Gunnar Mowé, MD, Vidar Skaug, MD, Axel Wannag, MD ${ }^{1}$
}

\begin{abstract}
GYLSETH B, MOWE G, SKAUG V, WANNAG A. Inorganic fibers in lung tissue from patients with pleural plaques or malignant mesothelioma. Scand $j$ work environ health 7 (1981) 109-113. The concentration of inorganic fibers in the lungs of patients with malignant mesothelioma and pleural plaques has been compared to that of patients without cancer or chronic respiratory diseases. The fiber concentrations have been determined by scanning electron microscopy and given as number of fibers per gram of dried tissue. A statistically significant difference in inorganic fiber content was found between the different groups.
\end{abstract}

Key terms: asbestos-related diseases, occupation, scanning electron microscopy.

The pathogenesis of asbestos-related diseases of the lungs and pleura is not fully understood, buit animal experiments $(2,9$, 11) indicate that fiber dimension is a relevant factor. The content of inorganic fibers in the lungs of exposed workers has also been related to the human pathological reaction $(1,12)$.

In this paper we have compared the asbestos concentration in lung tissue from patients with malignant mesothelioma of the pleura and from patien's with pleural plaques to that of a reference group comprising patients who died of coronary or cerebrovascular diseases.

\section{Subjects and methods}

\section{Subjects}

Lung tissue was analyzed from a total of 41 patients who were divided into three different groups.

Mesothelioma group. One group consisted of 15 patients (numbers $1-15$ ) with a post-

1 Institute of Occupational Health, Oslo, Norway.

Reprint requests to: $\mathrm{Mr}$ Bjørn Gylseth, Institute of Occupational Health, PO Box 8149 Dep, Oslo 1, Norway. mortem diagnosis of malignant mesothelioma. It included the first 15 patients recorded in an epidemiologic study. There were two insulators and four asbestos cement workers in the group, all probalbly having had a high occupational exposure to asbestos. Information about occupational exposure was obtained from different sources, eg, personal interviews, industrial physicians, and social insurance offices.

Pleural plaque group. Another group comprised 14 patients (numbers 16-29) with parietal pleural plaques of an individual size, recorded during autopsy, of at least $3 \times 3 \mathrm{~cm}$. This was the only criterion used for the selection of the lung tissue in these cases. Information about occupational exposure was not available.

Reference group. The third group consisted of 12 patients (numbers $30-41$ ) who had died of coronary or cerebrovascular diseases. The lung tissue specimens were obtained during consecutive hospital autopsies, with the exception that specimens from persons under 40 a of age or with cancer or chronic respiratory diseases were excluded. Information about occupational exposure was not available. 


\section{Methods}

The subjects were traced through close cooperation with various pathological departments and from information from the Cancer Registry of Norway. Tissue was obtained as whole lung specimens, pieces of lung, or paraffin-embedded autopsy material.

The samples comprised a cut from the pleura and a few centimeters into the central part of the lung. As intra- and interlobar fiber concentration variations occur (10), tissue was sampled from both the upper and lower lobes.

Normally, tissue from the left lung was taken; however, in the cases of complete tumor affection of the lung, as for many of the mesotheliomas, samples from the corresponding lobes of the right lung were analyzed. In the cases in which paraffinembedided material was analyzed, no information about tissue location was obtained. For patients for whom several analyses were made, the highest counts obtained have been given in the tables. In some cases only tumor-infiltrated lung tissue was available for the analysis, and the counts may have been low for these specimens.

Small tissue pieces were cut and dried. Organic material was removed by low- temperature plasma ashing. The ash was analyzed according to the methods described by Gylseth et al $(4,5)$. No effort was made to identify all fibers as long as only fibers broader than $0.1-0.2 \mu \mathrm{m}$ could be identified by our method.

\section{Results}

Table 1 presents relevant data on the 15 patien's with malignant pleural mesothelioma. The group included two insulation workers and four asbestos cement workers. The remaining nine, including two females, had had various occupations. We have not been able to trace any occupational exposure for the housewife with 41 million fibers per gram of dried tissue, while the other female had, in her youth, been employed in a company processing asbestos. The total group had a mean age of $65 \mathrm{a}$ at death. The time from first exposure until death varied from $19-59$ a, excluding cases 3,6 and 8 , for which no exposure data were obtained.

In table 2 the corresponding information is given for the 14 persons with pleural plaques. In this group, which had a mean age of 65 a at death, exact information about exposure was not obtained.

The results for the reference group, which comprised 12 persons, are given in

Table 1. Age, sex, occupation, latency period and fiber concentration in the lungs of the subjects with malignant mesothelioma.

\begin{tabular}{|c|c|c|c|c|c|c|}
\hline $\begin{array}{l}\text { Case } \\
\text { num- } \\
\text { ber }\end{array}$ & $\begin{array}{l}\text { Age } \\
\text { (a) }\end{array}$ & Sex a & Occupation & $\begin{array}{l}\text { Latency period } \\
\text { (a) }\end{array}$ & $\begin{array}{l}\text { Million fibers } \\
\text { per gram of } \\
\text { dried tissue }\end{array}$ & Remarks b \\
\hline 1 & 61 & $M$ & Insulator & 45 & 254 & A \\
\hline 2 & 72 & $M$ & Asbestos cement worker & 27 & 112 & A \\
\hline 3 & 60 & $\mathrm{~F}$ & Housewife & - & 41 & $\mathrm{~B}$ \\
\hline 4 & 71 & M & Tilesetter & 38 & 7.8 & B \\
\hline 5 & 60 & $M$ & Crane operator & 33 & 2.0 & $\mathrm{~B}$ \\
\hline 6 & 78 & $M$ & Pensioned & - & 6.1 & \\
\hline 7 & 79 & $\mathrm{~F}$ & Cashier & 59 & 11 & \\
\hline 8 & 61 & $M$ & Cellulose factory worker & - & 2.0 & B \\
\hline 9 & 56 & M & Insulator & 19 & 74 & \\
\hline 10 & 70 & $M$ & Asbestos cement worker & 28 & 83 & \\
\hline 11 & 55 & $M$ & Asbestos cement worker & 34 & 490 & C \\
\hline 12 & 62 & $M$ & Carpenter & 45 & 5.8 & D \\
\hline 13 & 77 & M & Chemical industry worker & 51 & 8.0 & \\
\hline 14 & 50 & M & Chemical industry worker & 22 & 4.2 & A \\
\hline 15 & 65 & M & Asbestos cement worker & 40 & 206 & \\
\hline
\end{tabular}

a $M=$ male, $F=$ female.

b $A=$ paraffin-embedded material of unknown location; $B=$ formaldehyde-preserved tissue of unknown location; $\mathrm{C}=$ right upper lobe; $\mathrm{D}=$ right lower lobe. 
table 3. Four patients had retired, and no information about previous occupations was given. Their mean age at death was 66 a.

When the lung fiber concentrations of each group were used in the calculations, a statistically significant difference $(p<0.01)$ was found between the groups (Wilcoxon's sum of ranks test).

In table 4 the results for all three groups are summarized.

\section{Discussion}

The dose required for the initiation of malignant mesothelioma is small and may even be acquired in nonoccupational exposure to asbestos $(3,7,8)$. It has been stated that the mesothelioma rate increases as intensity, duration of exposure, and time from first asbestos exposure increases (1). Whitwell et al (12) have suggested that a definite relationship exists

Table 2. Age, sex, cause of death, occupation and fiber concentration in the lungs of the subjects with pleural plaques.

\begin{tabular}{|c|c|c|c|c|c|c|}
\hline $\begin{array}{l}\text { Case } \\
\text { num- } \\
\text { ber }\end{array}$ & $\begin{array}{l}\text { Age } \\
\text { (a) }\end{array}$ & Sex a & Cause of death & Occupation & $\begin{array}{l}\text { Million } \\
\text { fibers per gram } \\
\text { of dried tissue }\end{array}$ & Remarks b \\
\hline 16 & 51 & $M$ & $\begin{array}{l}\text { Squamous cell carcinoma } \\
\text { of hypopharynx }\end{array}$ & Machine engineer & 3.9 & \\
\hline $\begin{array}{l}17 \\
18 \\
19 \\
20 \\
21\end{array}$ & $\begin{array}{l}70 \\
55 \\
60 \\
59 \\
76\end{array}$ & $\begin{array}{l}M \\
M \\
M \\
M \\
M\end{array}$ & $\begin{array}{l}\text { Carcinoma of bronchus } \\
\text { Myocardial infarction } \\
\text { Myocardial infarction } \\
\text { Astrocytoma grade III-IV } \\
\text { Anaplastic large cell }\end{array}$ & $\begin{array}{l}\text { Coppersmith } \\
\text { Undersealing worker } \\
\text { Machine engineer } \\
\text { Carpenter }\end{array}$ & $\begin{array}{c}13 \\
1.0 \\
1.8 \\
4.4\end{array}$ & $\begin{array}{l}\mathrm{B} \\
\mathrm{B} \\
\mathrm{B} \\
\mathrm{B}\end{array}$ \\
\hline $\begin{array}{l}22 \\
23\end{array}$ & $\begin{array}{l}75 \\
77\end{array}$ & $\begin{array}{l}M \\
M\end{array}$ & $\begin{array}{l}\text { carcinoma of lung } \\
\text { Sarcoidosis } \\
\text { Hodgkins disease, mixed }\end{array}$ & $\begin{array}{l}\text { Shipyard worker } \\
\text { Shopkeeper }\end{array}$ & $\begin{array}{l}2.1 \\
6.8\end{array}$ & \\
\hline $\begin{array}{l}24 \\
25\end{array}$ & $\begin{array}{l}68 \\
65\end{array}$ & $\underset{M}{\mathbf{M}}$ & $\begin{array}{l}\text { type } \\
\text { Diffuse lymphosarcoma } \\
\text { Squamous cell carcinoma }\end{array}$ & $\begin{array}{l}\text { Customs officer } \\
\text { Housewife }\end{array}$ & $\begin{array}{l}2.3 \\
1.0\end{array}$ & \\
\hline $\begin{array}{l}26 \\
27\end{array}$ & $\begin{array}{l}46 \\
66\end{array}$ & $\begin{array}{l}M \\
M\end{array}$ & $\begin{array}{l}\text { of lung } \\
\text { Drowning } \\
\text { Adenocarcinoma of }\end{array}$ & $\begin{array}{l}\text { Foundry worker } \\
\text { Unknown }\end{array}$ & $\begin{array}{l}0.8 \\
2.6\end{array}$ & B \\
\hline $\begin{array}{l}28 \\
29\end{array}$ & $\begin{array}{l}65 \\
72\end{array}$ & $\begin{array}{l}M \\
M\end{array}$ & $\begin{array}{l}\text { prostate } \\
\text { Diffuse lymphosarcoma } \\
\text { Squamous cell carcinoma } \\
\text { of lung }\end{array}$ & $\begin{array}{l}\text { Bank director } \\
\text { Paper-mill worker } \\
\text { Shipyard worker }\end{array}$ & $\begin{array}{l}0.1 \\
1.2\end{array}$ & \\
\hline
\end{tabular}

a $\mathrm{M}=$ male, $\mathrm{F}=$ female.

b $\mathrm{B}=$ formaldehyde-preserved tissue of unknown location.

Table 3. Age, sex, cause of death, occupation and fiber concentration in the lungs of the referents.

\begin{tabular}{|c|c|c|c|c|c|}
\hline $\begin{array}{l}\text { Case } \\
\text { number }\end{array}$ & $\begin{array}{l}\text { Age } \\
\text { (a) }\end{array}$ & Sex a & Cause of death & Occupation & $\begin{array}{l}\text { Million fibers per } \\
\text { gram of dried tissue }\end{array}$ \\
\hline $\begin{array}{l}30 \\
31 \\
32 \\
33 \\
34 \\
35 \\
36 \\
37 \\
38 \\
39 \\
40 \\
41\end{array}$ & $\begin{array}{l}67 \\
73 \\
36 \\
78 \\
72 \\
81 \\
49 \\
63 \\
90 \\
78 \\
53 \\
51\end{array}$ & $\begin{array}{l}F \\
M \\
F \\
M \\
F \\
F \\
M \\
M \\
M \\
M \\
M \\
M\end{array}$ & $\begin{array}{l}\text { Myocardial infarction } \\
\text { Acute pancreatitis } \\
\text { Embolus of the lung } \\
\text { Myocardial infarction } \\
\text { Myocardial infarction } \\
\text { Acute pyelonephritis } \\
\text { Subarchnoid hemorrhage } \\
\text { Myocardial infarction } \\
\text { Infarction of intestine } \\
\text { Bronchopneumonia } \\
\text { Cardiomyopathy } \\
\text { Dissecting aneurysm of } \\
\text { the aorta }\end{array}$ & $\begin{array}{l}\text { Housewife } \\
\text { Storesman } \\
\text { Clerical officer } \\
\text { Clerk } \\
\text { Pensioned } \\
\text { Pensioned } \\
\text { Clerk assistant } \\
\text { Union leader } \\
\text { Pensioned } \\
\text { Pensioned } \\
\text { Timberman } \\
\text { Driver }\end{array}$ & $\begin{array}{l}0.2 \\
0.5 \\
0.6 \\
0.6 \\
0.1 \\
0.9 \\
1.1 \\
1.3 \\
0.3 \\
0.1 \\
0.8 \\
\\
2.3\end{array}$ \\
\hline
\end{tabular}

a $\mathrm{F}=$ female, $\mathrm{M}=$ male. 
Table 4. Summary of the data on asbestos fiber concentration.

\begin{tabular}{cccc}
\hline $\begin{array}{l}\text { Asbestos fiber } \\
\text { concentration }\end{array}$ & $\begin{array}{c}\text { Patients with } \\
\text { malignant } \\
\text { mesothelioma }\end{array}$ & $\begin{array}{c}\text { Patients with } \\
\text { pleural plaques }\end{array}$ & Referents \\
\hline$<10^{6}$ & 0 & 2 & 9 \\
$10^{6}-10 \times 10^{6}$ & 7 & 11 & 3 \\
$10 \times 10^{6}-100 \times 10^{6}$ & 4 & 1 & 0 \\
$>100 \times 10^{6}$ & 4 & 0 & 12 \\
\hline Total number & 15 & 14 & \\
\hline
\end{tabular}

between the number of fibers and the presence of mesoltheliomas.

Scanning electron microscopy (SEM) is traditionally not used for the analysis of fibers in lung itissue. However, if we compare our results to data from similar studies obtained either by optical microscopy or by transmission electron microscopy, the results are at least within the same order of magnitude $(1,12)$. As stated in our previous work (10), mainly amphibole fibers are found, including crocidolite, amosite and anthophyllite. Chrysotile is, probably due to lack of sensitivity of the method, seldom found. Therefore, no effort has been made to identify the broadest fibers, all of them with a morphology corresponding to the amphiboles.

All the patients in the mesothelioma group had two million fibers or more per gram of dried tissue, whereas only one person in the reference group had that many fibers (a driver). According to our method of analysis $(4,5)$, the persons who had not been occupationally exposed had normally less than one to two million fibers per gram of dried tissue. As expected, the insulation workers and the workers in the asbestos cement industry had the highest exposures. The occupation given for the other patients in this group may also indicate previous asbestos exposure, but to a less degree than for the insulation and asbestos cement workers.

There were two females in the mesothelioma group, one with a considerable fiber concentration in her lungs (41 million fibers per gram of dried tissue). No previous occupational asbestos exposure was found for the woman with the highest fiber content. However, occupational exposures of short duration are difficult to pinpoint and cannot be excluded in this case. Household exposure cannot be excluded either. The other female had, at an age of approximately 20 a worked in a company importing asbestos from South Africa. The exposure was probably rather short. The results from this woman suggest that a significant number of fibers is retained in the lungs for a long time.

Evidence exists of an association between pleural plaques and asbestos exposure (6). However, few reports have been published as to the fiber concentrations in the lungs of persons with pleural plaques. Our data indicate a rather low and possibly intermittent exposure for most of the subjects with pleural plaques, ie, if fiber concentration reflects exposure. Thus pleural plaques may be associated with low asbestos exposure and low lung fiber concentrations, if asbestos were the only causative agent in these cases. Many of the patients in the pleural plaque group died of a primary cancer, and therefore the results may be biased. However, we have no evidence thus far of cancer patients without pleural plaques having a higher lung fiber concentration than that of the reference group.

According to the median lung fiber concentration, the mesothelioma group had eighteen times higher values than the reference group, while the corresponding numbers for the pleural plaque group were approximately four times that of the reference group. The results demonstrate a significant difference in lung fiber burden between the respective groups.

\section{Acknowledgments}

We gratefully acknowledge the staff of the pathological departments at the Norwegian Radium Hospital, the Norwegian 
State Hospital, the Ullevaal Municipal Hospital, and the Alker Hospital for providing us with lung tissue samples. We thank the Cancer Registry of Norway for supplying us with data.

\section{References}

1. Ascroft T, Heppleston AG. The optical and electron microscopic determination of pulmonary asbestos fibre concentration, and its relation to the human pathological reaction. J clin pathol 26 (1973) 224-234.

2. Brown RC, Chamberlain M, Griffiths DM, Timbrell V. The effect of fibre size on the in vitro biological activity of three types of amphibole asbestos. Int $\mathrm{j}$ cancer 22 (1978) $721-727$.

3. Greenberg M, Davies TAL. Mesothelioma register $1967-68 . \mathrm{Br} \mathrm{j}$ ind med 31 (1974) $91-104$.

4. Gylseth B, Baunan RH, Bruun R. Analysis of inorganic fiber concentrations in biological samples by scanning electron microscopy. Scand $\mathrm{j}$ work environ health 7 (1981) $101-108$.

5. Gylseth B, Ophus EM, Mowé G. Determination of inorganic fiber density in human lung tissue by scanning electron microscopy after low temperature ashing. Scand $j$ work environ health 5 (1979) $151-157$.

Received for publication: 23 December 1980
6. Jones JSP, Sheers G. Pleural plaques. In: Bogovski P, Gilson JC, Timbrell V, Wagner $\mathrm{JC}$, ed. Biological effects of asbestos. International Agency for Research on Cancer, Lyon 1973, pp 243-248. (IARC, no 8).

7. Newhouse ML. Asbestos in the work place and the community. Ann occup hyg 16 (1973) $97-107$.

8. Newhouse ML, Thompson $H$. Mesothelioma of pleura and peritoneum following exposure to asbestos in the London area. $\mathrm{Br} \mathrm{j}$ ind med 22 (1965) 261-269.

9. Pott F, Friedrichs KH, Huth F. Ergebnisse aus Tierversuchen zur kanzerogenen Wirkung faserförmiger Stäube und ihre Deutung in Hinblick auf die Tumorentstehung beim Menschen. Zentralbl Bakteriol Parasitenkd Infektionskr Hyg Abt 1 Orig B 162 (1976) 467-505.

10. Ophus EM, Mowé G, Osen KK, Gylseth B. Scanning electron microscopy and $x$-ray microanalysis of mineral deposits in lungs of a patient with pleural mesothelioma. $\mathrm{Br}$ $j$ ind med 37 (1980) 375-381.

11. Stanton MF, Layard M, Tegeris A, Miller E, May M, Kent E. Carcinogenicity of fibrous glass: Pleural response in the rat in relation to fiber dimension. $J$ natl cancer inst 58 (1977) $587-603$.

12. Whitwell F, Scott J, Grimshaw M. Relationship between occupations and asbestos fibre content of the lungs in patients with pleural mesothelioma, lung cancer, and other diseases. Thorax 32 (1977) $377-386$. 